\title{
Establishment of In-House Quantitative Real-Time RT-PCR Assay for HIV- 1 Viral Load Measurement: Application to Evaluate Efficacy of ART in Ghanaian Patients in an Urban Setting
}

Jacob Samson Barnor ${ }^{1 *}$, Norio Yamamoto ${ }^{2,5}$, James Ashun Mensah Brandful ${ }^{1}$, William Ampofo ${ }^{1}$, Joseph Humphrey Kofi Bonney ${ }^{1}$, Evelyn Bonney $^{1}$, John Kofi Odoom ${ }^{1}$, Simeon Aidoo ${ }^{1}$, Michael Alale ${ }^{1}$, Nana Afia Ntim ${ }^{1}$, Yaw Owusu Amoah ${ }^{1}$, Sampson Badu Ofori ${ }^{3}$, Jerry Ndzinu ${ }^{1}$, Ishmael Dzigbordi Aziati' ${ }^{1}$, Nii-Akwei Addo4, Alexander Nyarko', Eiji Ido ${ }^{1,2}$, Koichi Ishikawa ${ }^{2,5}$ and Shoji Yamaoka ${ }^{2}$

${ }^{1}$ Virology Department, Noguchi Memorial Institute of Medical Research, Legon-Accra, Ghana

${ }^{2}$ Department of Molecular Virology, Tokyo Medical and Dental University, Japan

${ }^{3}$ HIVIAIDS Clinic, Koforidua Regional Hospital, Koforidua, Ghana

${ }^{4}$ National AIDS Control Program, Ghana

${ }^{5}$ National Institute of Infectious Diseases, Tokyo, Japan

\begin{abstract}
The aim of this study was to establish and apply a real-time quantitative reverse transcription polymerase chain reaction (RT-PCR) for human immunodeficiency virus (HIV) RNA quantification in patients on antiretroviral treatment (ART) in Ghana, where recombinant strains including CRF02_AG are prevalent. The primers and TaqMan probe concentrations as well as reaction temperatures were optimized to establish an efficient in-house quantitative assay system for HIV RNA, a tool for HIV viral load measurement in patients. Then an already established HIV-specific PCR amplicon (HIV-1 ${ }_{N 4-3}$ ) was used as an external standard to estimate the linearity, amplification efficiency, analytical sensitivity and reproducibility of the in-house real time quantitative assay. Finally, the assay was applied to quantify the viral load in clinical samples of HIV patients on ART. The real time quantitative assay was shown to have good linearity $\left(R^{2}=1.0\right)$, high amplification efficiency $(E=1.91)$, high sensitivity (180 copies/ml), and high reproducibility (variation coefficient range, from $1.25 \%$ to $3.58 \%$ ). Analytical specificity and sensitivity of the assay in clinical samples was $96.7 \%$ and $95.0 \%$, respectively. The established tool is reliable and covers all relevant genotypes including rare and recombinant forms that circulate in the sub-region. It could therefore allow general monitoring of antiretroviral therapy in patients living in resource-limited settings due to its simplicity, rapidity and less-labour intensiveness.
\end{abstract}

Keywords: ART; Evaluation; Ghana; HIV; qRT-PCR; Viral load

Abbreviations: HIV: Human Immunodeficiency Virus; ART: Antiretroviral treatment; PMTCT: Prevention of mother-to-child transmission; qRT-PCR: Quantitative reverse transcription-polymerase chain reaction; NASBA: Nucleic acid sequence-based amplification; LTR: Long terminal repeat

\section{Introduction}

Antiretroviral therapy (ART) can effectively manage human immunodeficiency virus type 1 (HIV-1) infection. Lower ART costs make treatment programs possible in non affluent countries, where $95 \%$ of HIV infections occur [1,2]. However, patients receiving antiretroviral therapy (ART) frequently develop treatment resistance. A key determinant of treatment failure is an increase in viral load, tests for which generally are not available in developing countries. As such, the WHO developed guidelines for ART failure that are based upon CD4 counts and clinical criteria, as these measures are generally available [3]. However, objective evaluation of these criteria has shown that there is always poor correlation between these parameters for clinical evaluation of patients. The quantification in plasma of human immunodeficiency virus type 1 (HIV-1) RNA is therefore a necessary useful test for predicting clinical outcome, evaluating disease progression, and monitoring the effect of ART on HIV-1-infected patients $[4,5]$.

Programs to scale-up ART in resource-limited countries have lately received a lot of attention in the last 7 years [6,7]. Currently, almost 1.5 million people in these countries are receiving ART and the number continues to grow. However, due to limited resources and inadequate laboratory capacity, many programs have minimized the laboratory monitoring of patients on treatment, in an effort to accelerate the widespread availability of the antiretroviral drugs [8].
There are, however, several reasons why equal efforts should be made to implement HIV-1 RNA viral load monitoring in these regions. The inability to detect early virological failure could lead to an accumulation of drug-resistant mutations and the selection of viruses with broad cross resistance to antiretroviral drugs. An increasing number of patients carrying drug-resistant virus will inevitably lead to a spread of these resistant strains in the population.

Hence, ART should as a matter of compulsion include accurate monitoring of plasma virus concentrations (viral load) [2,9-12]. There is therefore an urgent need for low-cost, simple, and accurate HIV-1 viral load monitoring technologies in resource-limited settings, particularly at the time of the scaling-up of first- and second-line ARTs. Earlier, for the prevention of mother-to-child transmission (PMTCT), virus detection is required for testing newborns and mothers' milk. However, in current practice viral load in mothers'milk is used as a correlate to plasma viral load, and therefore plasma viral load suppression considerably reduces the risk of transmission through breastfeeding. Testing for HIV-1 in the context of ART and PMTCT is best done

*Corresponding author: Jacob Samson Barnor, Noguchi Memorial Institute for Medical Research, College of Health Sciences, University of Ghana, Box LG 581, Legon, Accra, Ghana, Tel: 233-(0)242885646; E-mail: jbarnor@noguchi.ug.edu.gh

Received March 26, 2014; Accepted April 25, 2014; Published May 05, 2014

Citation: Barnor JS, Yamamoto N, Brandful JAM, Ampofo W, Bonney JHK, et al. (2014) Establishment of In-House Quantitative Real-Time RT-PCR Assay for HIV-1 Viral Load Measurement: Application to Evaluate Efficacy of ART in Ghanaian Patients in an Urban Setting . J AIDS Clin Res 5: 305. doi:10.4172/2155-6113.1000305

Copyright: ( 2014 Barnor JS, et al. This is an open-access article distributed unde the terms of the Creative Commons Attribution License, which permits unrestricted use, distribution, and reproduction in any medium, provided the original author and source are credited. 

Assay for HIV-1 Viral Load Measurement: Application to Evaluate Efficacy of ART in Ghanaian Patients in an Urban Setting . J AIDS Clin Res 5: 305. doi:10.4172/2155-6113.1000305

by molecular methods, e.g., reverse transcription-PCR (RT-PCR), nucleic acid sequence-based amplification (NASBA), or branched DNA (bDNA) assays [10,11,13-16]. Because of the high diversity of HIV-1, assay design is extraordinarily demanding. Therefore, viral load testing relies almost exclusively on expensive commercial tests. With decreasing prices for drugs in many countries, therapy monitoring has become more expensive than the treatment itself $[17,18]$, a situation that leads to insufficient therapy monitoring, suboptimal patient management, and increased risk for emergence of drug-resistant virus strains. In addition, because they have been optimized for strains prevalent in the Northern Hemisphere, many commercial tests are not accurate for testing "exotic" HIV-1 subtypes found mainly in developing countries [19]. Moreover, some commercial assays are based on the gag gene, which is too variable for detection of outlier strains [20], and hence consequently in using such assays, certain HIV-1 subtypes and recombinants may not be detected $[21,22]$.

There is therefore an urgent need for low-cost, simple, and accurate HIV-1 viral load monitoring technologies in resource-limited settings, particularly at the time of the scaling-up of first and second-line highly active antiretroviral therapies $[23,24]$. Technological improvements, from automated sample isolation to real time amplification technology, have given the ability to develop and introduce systems for most viruses of clinical interest, and to obtain clinically relevant information needed for optimal ART options $[25,26]$. On the basis of this established experience [20], we have developed an inexpensive real-time quantitative RT-PCR viral-load assay that at least equals to commercial tests with regard to technical features and performance. Instead of the gag gene, it targets the highly conserved long terminal repeat (LTR) region, thereby providing a spectrum of detectable and quantifiable genotypes beyond that of current assays. Without doubt, the fluorescence-based real-time RT-PCR is widely used for the quantification of steady-state mRNA levels and is a critical tool for basic research, molecular medicine and biotechnology. Assays are easy to perform, capable of high throughput, and can combine high sensitivity with reliable specificity.

\section{Material and Methods}

Gold standard for monitoring antiretroviral treatment success or failure, HIV patients and clinical samples

According to the guide line and criteria for management of HIV patients on antiretroviral treatment advanced and approved by the Ministry of Health of Ghana, plasma viral load measurement (gold standard test) augmented with the dynamics of CD4 and CD8 counts and other clinical parameters serve as index for treatment success or failure. There were a total of 405 HIV patients on ART recruited for cross-sectional monitoring at the Koforidua Government Hospital during the application of the in-house quantitative real-time RT-PCR (qRT-PCR) evaluation of efficacy. From the 405 patients, veinomous blood from patients was collected in vacutainer tubes containing EDTA (Becton Dickinson, USA) with informed consent approved by both the ethics committees of Noguchi Memorial Institute for Medical Research, University of Ghana and Tokyo Medical and Dental University. Plasma separated from the whole blood was stored in individual cryo-vials at $-80^{\circ} \mathrm{C}$ until required for use. The mean age of the HIV-1 seronegative subjects was 27.5 years (S.D \pm 5.9$), 11(55.0 \%)$ of them were women. The mean age of the HIV-1-infected patients was 36.9 (S.D \pm 9.2 ) years, $286(70.6 \%)$ were women and $51.3 \%$ of all infected patients were in clinical stage 3 or 4 [27]. Median CD4 cell counts, available for 143 of the HIV-infected patients, was 243 cells $/ \mathrm{mm}^{3}$ (IQR 138-405 cells/ $\mathrm{mm}^{3}$ ). Patients on ART were on treatment for a mean of 13 months (ranging from 2 weeks to 33 months). All the plasma collected from 405 HIV patients and 20 healthy negative donors as negative control were tested in three independent runs in duplicates by the established in-house qRT-PCR assay.

\section{Preparation of the PCR amplicon DNA from HIV}

To evaluate the real-time qRT-PCR, we used the existing laboratory strain $\mathrm{HIV}_{\mathrm{NL} 4-3}[28]$ as a standard for the assay in the laboratory. Primers were designed from the highly conserved region of 97GH-AG2 (fulllength sequence was submitted to DDBJ/EMBL/GenBank and is available under accession number AB052867) isolated by the Virology laboratory at the Noguchi Memorial Institute in Ghana [29], to test the amplification efficiency since it represents the major strain driving infection in Ghana. The forward primer was 5'-CAG CTG CTT TTT GCC TGT AC-3', and the reverse primer was 5'-AGC ACT CAA GGC AAG CTT TA-3'. Primers were chemically synthesized by Invitrogen (Japan). The HIV amplicon was made by conventional PCR using plasmid vector containing pBluscriptII-LTR by the laboratory as a template in the T-1 Thermal Cycler. The PCR mixtures were composed of $1.0 \mu \mathrm{l}$ of each primer $(25 \mu \mathrm{M}), 0.5 \mu \mathrm{l}$ of $E x$-Taq $(5 \mathrm{U} / \mu \mathrm{l})$ (Takara, Otsu, Japan), $5 \mu$ of $10 \times L A$ PCR buffer II $\left(\mathrm{Mg}^{2+}\right.$ free $), 5 \mu$ of $\mathrm{MgCl}_{2}(25$ $\mathrm{mM}$ ), $8 \mu \mathrm{l}$ of dNTP mixtures (each $2.5 \mathrm{mM}$ ), $10 \mu \mathrm{l}$ of pBluscriptII-LTR template, and $19.5 \mu \mathrm{l}$ of the distilled water added to a final volume of $50 \mu \mathrm{l}$. The HIV amplicon cDNA was amplified by conventional PCR for 35 cycles at $93^{\circ} \mathrm{C}$ for $45 \mathrm{~s}, 55^{\circ} \mathrm{C}$ for $1 \mathrm{~min}$ and $72^{\circ} \mathrm{C}$ for $3 \mathrm{~min}$. The final extension step was conducted for $5 \mathrm{~min}$ at $72^{\circ} \mathrm{C}$. Plasmid pET30a (+) DNA was used as a negative control. The PCR products were analyzed by $1 \%$ agarose gel electrophoresis. Then, a significant amount of the amplicon, produced by many PCR reactions was purified by an EZNA spin gel extraction kit (Omega, Doraville, USA). Purified LTR PCR amplicon was quantified by the $H I V$ fluorescence PCR diagnostic kit (Gene Diagnosis Inc., Japan) on ABI Prism 7300 (Applied Biosystems, Foster City, USA).

\section{Nucleic acid purifications}

Nucleic acids were extracted from a $0.2-\mathrm{ml}$ volume of plasma. RNA was purified from plasma with a RNA extraction protocol (QIAamp viral RNA kit; QIAGEN, Germany) according to the manufacturers' recommendations. The total nucleic acids were eluted in $100 \mu$ l of RNase- and DNase-free water. All purification runs included one previously tested negative and positive control samples.

\section{Oligonucleotide design and comparison of sensitivity of each primer-probe set}

The LTR and Gag were selected as highly conserved region in HIV1 according to the HIV sequence database (Los Alamos database, http:// hiv-web.lanl.gov/ content/hiv-db/mainpage.html). Sets of primers and a probe were designed in these regions based on the sequence of subtype B (NL4-3, of which GenBank accession is M19921) and CRF02-AG (97GH-AG2, of which GenBank accession is AB049811). The sequences of designed primers and probes are as follows: set 1-fwd, 5'- GCC TCA ATA AAG CTT GCC TTG A-3'; set 1-rv, 5'- GGC GCC ACT GCT AGA GAT TTT-3'; set 1-probe, 5'-FAM-AAG TAG TGT GTG CCC GTC T-TAMRA-3' (LNAs are underlined); set 2-fwd, 5'GCC TCA ATA AAG CTT GCC TTG A-3'; set 2-rv, 5'- GGC GCC ACT GCT AGA GAT TTT-3'; set 2-probe, 5'-FAM-AAG TAG TGT GTG CCC GTC T-Quencher-MGB-3'; set 3-fwd, 5'- CAG GCA GCA ATG CAG ATG TTA A-3'; set 3-rv, 5'- AGT AGT TCC TGC TAT GTC ACT TCC C-3'; set 3-probe, 5'-FAM-CAG TAC ATG CAG GGC CTA TTC CAC CAG-TAMRA-3'; set 4-fwd, 5'-CAA GCA GCC ATG CAA 
Citation: Barnor JS, Yamamoto N, Brandful JAM, Ampofo W, Bonney JHK, et al. (2014) Establishment of In-House Quantitative Real-Time RT-PCR Assay for HIV-1 Viral Load Measurement: Application to Evaluate Efficacy of ART in Ghanaian Patients in an Urban Setting . J AIDS Clin Res 5: 305. doi:10.4172/2155-6113.1000305

Page 3 of 7

ATG TTA A-3'; set 4-rv, 5'-AGT AGT TCC TGC TAT GTC ACT TCC C-3'; set 4-probe, 5'- FAM-CAG TGC ATG CAG GGC CTA TTG CAC CAG-TAMRA-3'; set 5-fwd, 5'-GTA GTG TGT GCC CGT CTG TTG3'; set 5-rv, 5'-CAA GCC GAG TCC TGC GT-3'; set 5-probe, 5'-FAMTGG CGC CCG AAC AGG GACT T-TAMRA-3'.

For preparation of viruses, HEK 293T cells in 6-well-plates were transfected with $2 \mu \mathrm{g}$ of the plasmid encoding NL4-3 or 97GH-AG2 using $6 \mu \mathrm{l}$ of FuGENE 6 (Roche), according to the manufacturers' protocol. Culture medium was changed after $12 \mathrm{~h}$ of incubation, and culture supernatant was collected $24 \mathrm{~h}$ after changing culture medium. The concentration of p24 in the collected culture supernatants was measured with the HIV-1 p24 CLEIA assay. Virus-containing medium was diluted to make the concentration of NL4-3 p24 to be 100 ng per $140 \mu \mathrm{l}$ and that of $97 \mathrm{GH}-\mathrm{AG} 2 \mathrm{p} 24$ to be 100 pg per $140 \mu \mathrm{l}$. RNA was extracted from $140 \mu \mathrm{l}$ of the diluted virus-containing medium by using viral RNA purification kit (QIAGEN). Purified RNA was subjected to quantification by real-time RT-PCR assay with 5 primer-probe sets. Cycle threshold value (CT value) was compared to identify the primerprobe set with the highest sensitivity.

\section{Plasma HIV-1 RNA quantification by real-time RT-PCR assay}

Briefly, RNA was extracted from $200 \mu$ of stored $\left(-70^{\circ} \mathrm{C}\right)$ plasma by using the QIAGEN procedure. The TaqMan PCR target was a conserved consensus region in the long terminal repeat (LTR) region of the HIV-1 major group. The primer/probe set 1 was used in this study. All runs were performed in a $50-\mu \mathrm{l}$ volume containing RNA extract $(20$ $\mu \mathrm{l})$, primers (a $500 \mathrm{nM}$ concentration of each), probe $(200 \mathrm{nM}), 1 \times \mathrm{PCR}$ buffer, and $1 \times$ RT RNase Inhibitor Mix (Taqman One-Step RT-PCR Master Mix; Applied Biosystems).

\section{Statistical analysis}

Linear regression was used to analyse the data obtained from the standard curve of qRT-PCR in this research. The assessing parameters including amplification efficiency, specificity, sensitivity and reproducibility were analysed by SPSS for windows version 13.0 software (SPSS Inc, Chicago, IL USA). The correlation between results of three replicate runs by 2 independent operators at 3 different occasions for our in-house HIV RNA viral load assays were analyzed using Pearson's correlation coefficient ( $r$ ). Variability within-run and between-run was determined by calculating the coefficient of variation (CV) [30]. The analytical sensitivity of operator 1 and operator 2 were analyzed using $\mathrm{x}^{2}$ and Fisher probabilities.

\section{Results}

\section{HIV specific PCR amplicon standard}

An HIV specific PCR amplicon standard was prepared in the laboratory. The HIV amplicon was made by conventional PCR. In the electrophoresis gel, the HIV amplicon of a proper size (503 bp) was acquired as shown in Figure 1B. Then the amplicon produced by many PCR reactions was purified and quantified. The purified HIV PCR amplicon was measured in triplicate on ABI Prism 7300. The average concentration was $2.75 \times 10^{9}$ copies $/ \mu \mathrm{l}\left(2.70-2.80 \times 10^{9}\right.$ copies $\left./ \mu \mathrm{l}\right)$. The above-quantified HIV stock amplicon solution and a dilution of $2.75 \times 10^{9}$ copies $/ \mathrm{ml}$ used throughout the study as an external standard were then both kept at $-20^{\circ} \mathrm{C}$.

Linearity, amplification efficiency and detection limit of the TaqMan real-time quantitative RT-PCR assay

First, the sequences of the primers and TaqMan probes, their concentrations, and reaction temperatures were optimized to establish an efficient qRT-PCR assay for HIV RNA. Five sets of primers and a probe targeting HIV-1 LTR and gag were designed based on the sequence of NL4-3 laboratory strain and 97GH-AG2 Ghanaian CRF02_AG strain (Figure 1A). We analyzed sensitivity of these primer-probe sets using diluted viruses produced from 293T cells transfected with pNL4-3 or p97GH-AG2. Sensitivity analysis revealed that the primer-probe set 1 and 3 efficiently detect the Ghanaian CRF02-AG strain (97GH-AG2) (Figure 1C), while the primer-probe set 1 and 4 detect the NL4-3 strain (Figure 1D). Our primer-probe set 1 could sensitively quantify both

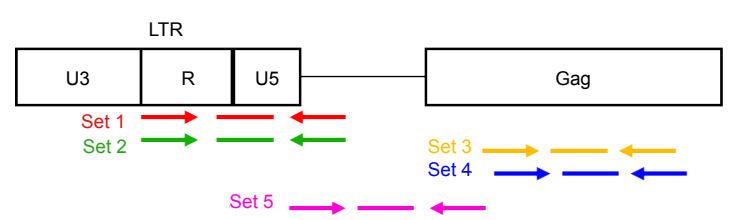

Figure 1a: Primer construction and selection within tile profile of tile LTR and Gag regions of HIV genome

Set 1 : matching completely to both subtype $B$ and CRF02-AG, with LNA probe. Set 2 :matching completely to both subtype Band CRF02-AG, with MGB probe. Set 4 : matching completely to CRFO2.AG and highly t.O subtype $B$. Set 5 : matching completely to subtype B and highly to CRF02-AG.

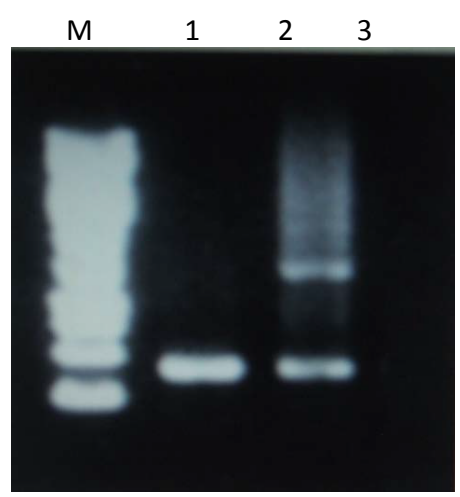

Figure 1b: HIV amplicon standards was electrophoresed in $1.5 \%$ agarose ge M, $1 \mathrm{~kb}$ ladder; lane 1, NL4-3; lane 2, 97GH-AG2 (Ghanaian isolate) ${ }^{\mathrm{a}}$ expected size of 503 bp respectively; lane 3 , distilled water (negative control). ${ }^{\text {aT }}$ The AG strains are currently driving the infections in Ghana.

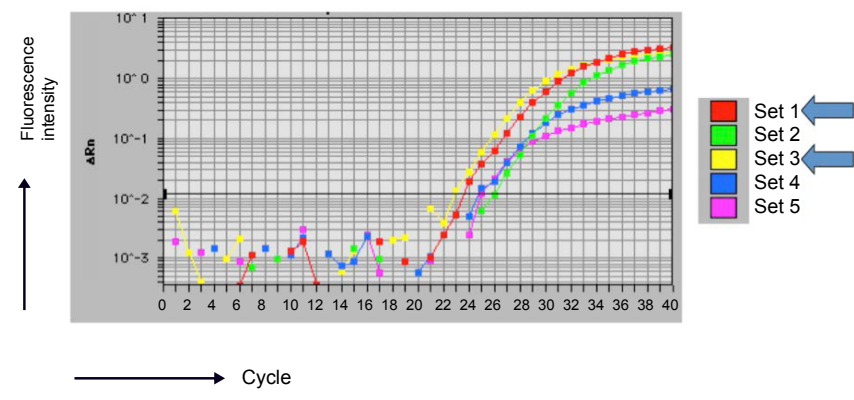

Figure 1C: Primer/probe set 1 and set 3 are the most sensitive sets to 97GH-AG2 viral RNA.

Viral RNA of $97 \mathrm{GH}-\mathrm{AG} 2$ was subjected to real-time RT-PCR with a series of primer/probe sets to determine the efficiency of the different primers sets. The amount of total RNA (including carrier RNA and viral RNA) was $100 \mathrm{ng}$ for each reaction. 
Citation: Barnor JS, Yamamoto N, Brandful JAM, Ampofo W, Bonney JHK, et al. (2014) Establishment of In-House Quantitative Real-Time RT-PCR Assay for HIV-1 Viral Load Measurement: Application to Evaluate Efficacy of ART in Ghanaian Patients in an Urban Setting . J AIDS Clin Res 5: 305. doi:10.4172/2155-6113.1000305

Page 4 of 7

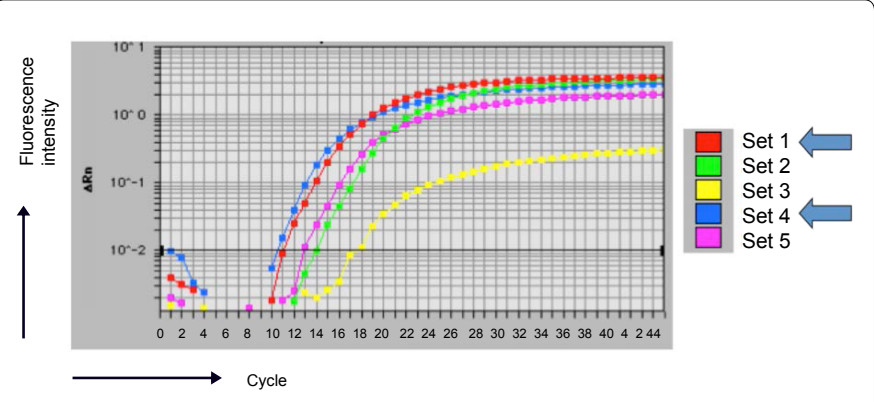

Figure 1D: Primer/probe set 1 and set 4 are the most sensitive sets to NL4-3 viral RNA.

Viral RNA of NL4-3 was subjected to real-time RT-PCR with a series of primer/ probe sets the efficiency of the different primers sets. The amount of total RNA (including carrier RNA and viral RNA) was $100 \mathrm{ng}$ for each reaction.

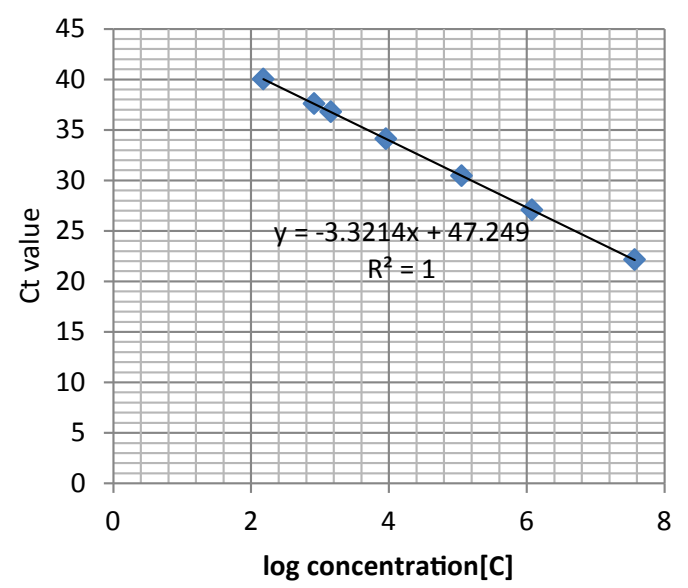

Figure 2: The linear relationship between log concentration and $\mathrm{Ct}$ values for a series of dilutions from $1 \times 10^{7}$ to $1 \times 10^{1}$ of HIV amplicon standard $\left(R^{2}=1.0\right)$ Each dilution of HIV amplicon standard was assayed in duplicate by quantitative RT-PCR.

\begin{tabular}{|c|c|c|}
\hline $\begin{array}{c}\text { HIV replicon standard } \\
\text { (Copies/ML) }\end{array}$ & $\begin{array}{c}\text { Number of positive samples/ } \\
\text { Number of tested samples }\end{array}$ & Positive (\%) \\
\hline 540 & $5 / 5$ & $100 \%$ \\
\hline 420 & $5 / 5$ & $100 \%$ \\
\hline 300 & $5 / 5$ & $100 \%$ \\
\hline 180 & $4 / 5$ & $80 \%$ \\
\hline 60 & $0 / 5$ & $0 \%$ \\
\hline
\end{tabular}

Table 1: Detection limit of the TaqMan HIV quantitative assay using a series of dilutions of HIV Amplicon Standard. subtype B and CRF02-AG, which means that the set 1 covers wider range of HIV-1 strain.

The TaqMan quantitative assay was carried out on a series of ten-fold dilutions from $1 \times 10^{7}$ to $1 \times 10^{1}$ of HIV amplicon standard and Ghanaian CRF02_AG, a major strain driving HIV infection in Ghana. The standard curve (Figure 2) was generated automatically. The standard curve showed the linear relationship between the log of the concentration of target RNA and the cycle threshold $(\mathrm{Ct})$ value. The correlation coefficient of the standard curve was 1.0, indicating a precise log-linear relationship between the concentration of target RNA and the $\mathrm{Ct}$ value. The regression equation was as Equation 1: $\mathrm{y}=-3.3206 x+$ 47.245 [1]. Based on conventional quantitative RT-PCR theory [31,32], the regression coefficient and the PCR amplification efficiency are related according to Equation $2: \mathrm{b}=-(1 / \mathrm{lgE})[2]$ where $\mathrm{E}$ is efficiency of PCR reaction, $b$ is regression coefficient (slope of the standard curve). According to the equation, the PCR amplification efficiency calculated was 1.91. The detection limit of the assay was determined by performing a series of dilutions of HIV amplicon standard for five repeats. The detection limit of the quantitative RT-PCR assay was 180 copies/mL (Table 1).

\section{Reproducibility of HIV-1 viral RNA quantification assay}

Variability of viral RNA quantification within-run and between run was determined by calculating the $\mathrm{CV}$ [30]. The CV of within-run by operator- 1 ranged from $0.34 \%$ to $4.12 \%$, and the $\mathrm{CV}$ of betweenrun values ranged from $2.10 \%$ to $6.41 \%$. The $\mathrm{CV}$ of the within-run operator- 2 activity ranged from $1.00 \%$ to $3.80 \%$, and the CV of betweenrun by operator- 2 ranged from $1.12 \%$ to $5.20 \%$. The variation of withinrun and between-run analyses was very low, as indicated in Table 2.

\section{Application of the real-time quantitative RT-PCR assay on clinical samples}

The real-time quantitative RT-PCR assay was applied to detect HIV RNA in plasma specimens collected from 405 study subjects. The quantification of HIV RNA showed that there was suppression of virus expression in 302 patients on ART and 99 patients showed varying degrees of viral load while four patients exhibited undetermined values which might probably mean the patients have no RNA detectable in their plasma due to ART (Table 3). Among the 30 plasma specimens collected from healthy persons in the control group, one was found falsely positive. Therefore the analytical specificity and sensitivity of the in-house HIV RNA quantitative RT-PCR assay were $96.7 \%$ and $95.0 \%$, respectively as indicated by the gold standard (Table 4). It was probable that the plasma specimens from the one patient sample which was negative could be due to failure of the inhibition of the RT-PCR inhibitors. The inhibitors of the RT-PCR negatively affect PCR amplification efficiency during template

\begin{tabular}{|c|c|c|c|c|c|c|c|}
\hline \multirow{2}{*}{ HIV RNAAssay Operators } & \multirow{2}{*}{ Sample Tested } & \multicolumn{3}{|c|}{ With-in Variation (Copies/ML) } & \multicolumn{3}{|c|}{ Between- run Variation (Copies/ML) } \\
\hline & & Run 1 & Run 2 & Run 3 & Mean & $\mathrm{SD}^{\mathrm{b}}$ & $\mathrm{CV}(\%)^{\mathrm{c}}$ \\
\hline \multirow{3}{*}{ Operator 1} & 1 & $49317 \pm 165$ & $51881 \pm 1321$ & $45640 \pm 261$ & 48933.57 & 3137.71 & 6.41 \\
\hline & 2 & $26121 \pm 656$ & $25177 \pm 1037$ & $24266 \pm 867$ & 25187.96 & 785.81 & 3.12 \\
\hline & 3 & $8092 \pm 162$ & $7831 \pm 125$ & $8194 \pm 139$ & 8039.00 & 168.31 & 2.12 \\
\hline \multirow{3}{*}{ Operator 2} & 1 & $50227 \pm 712$ & $53718 \pm 604$ & $55706 \pm 552$ & 53217.00 & 2750.25 & 5.20 \\
\hline & 2 & $25821 \pm 892$ & $25970 \pm 986$ & $27980 \pm 1012$ & 26590.00 & 1069.86 & 4.02 \\
\hline & 3 & $8235 \pm 205$ & $8521 \pm 161$ & $8408 \pm 198$ & 8388.00 & 94.70 & 1.12 \\
\hline
\end{tabular}

aAll samples were tested in triplicate for each run. Every run was operated by different operator on 3 independent occasions.

${ }^{b} B e t w e e n-a s s a y ~ S D s$ were calculated using the modified SD formula: [(SD of means) ${ }^{2}$ (mean with-assay SD $\left.)^{2} / 3\right]^{1 / 2}$

${ }^{c}$ The SD achieved was used to calculate the $\mathrm{CV}$ by using the formula $\mathrm{CV}=(\mathrm{SD} / \mathrm{mean}) \times 100$

Table 2: Reproducibility of in-house HIV RNA viral loada. 


\begin{tabular}{|l|c|c|}
\hline N=405 & Number of patients & Percentage \\
\hline Sex & 119 & \\
Male & 286 & 29.38 \\
Female & 0 & 70.62 \\
Undocumented & 200 & 0 \\
\hline Age & 202 & 49.38 \\
$\geq 40$ & 3 & 49.88 \\
<40 & & 0.74 \\
Undocumented & 132 & \\
\hline CD4 Count & 268 & 32.60 \\
$\geq 350$ & 5 & 66.17 \\
$<350$ & & 1.23 \\
Undocumented & 99 & \\
\hline HIV Viral Load & 302 & 24.44 \\
$\geq 180$ cop/mL & 4 & 74.57 \\
< 180 cop/mL & 0.99 \\
Undetected* & & \\
\hline
\end{tabular}

Table 3: Parameters of recruited HIV-infected patients on ART at the Koforidua Government Hospital.

\begin{tabular}{|l|c|c|c|c|}
\hline Assay & & \multicolumn{2}{|c|}{ Gold Standard } & Sum total \\
\hline & & + & - & \\
\hline qRT-PCR & + & 19 & 1 & 20 \\
\hline & - & 1 & 29 & 30 \\
\hline Sum total & & 20 & 30 & 50 \\
\hline
\end{tabular}

Table 4: Analytical specificity and sensitivity of the real-time quantitative RT-PCR assay for HIV RNA.

preparation. In addition, laboratory plastics have been identified as a potential source of PCR inhibitor [33].

\section{Discussion}

The challenge of how to appropriately monitor patients on antiretroviral treatment in resource-limited settings was only raised a few years ago with the increasing availability of ART in these regions [34]. In Western countries, follow-up of HIV infected individuals includes at least regular CD4 cell counts and viral load quantitations, supplemented with genotypic resistance testing in case of treatment failure [35]. Implementation of this procedure in resource-limited settings will far exceed the available budgets. In some countries, the combined cost of a CD4 cell count and a viral load test is higher than the cost of 2 months ART therapy [36]. A number of alternative methods for viral load testing, including p24 antigen detection, reverse transcriptase activity testing and real-time PCR assays for viral RNA quantitation have been evaluated by others [37] and good correlations were found between these assays and standard commercial viral load tests. However, most of these studies were performed in high-income countries and therefore did not take into account the possible logistical problems that might be encountered in resource-limited settings. In the study presented here, the immunocytometry assays for CD4 were performed on-site, in the Koforidua Government Hospital, a public regional referral hospital in Koforidua while the in-house viral load assay was performed at the Noguchi Memorial Institute for Medical Research in Accra.

In Ghana, HIV-infected patients with CD4+ T-cell counts $<350$ cells/ $\mu \mathrm{L}$ currently receive government-funded HAART, but methods of monitoring the effectiveness of therapy or disease progression are still prohibitively expensive for most patients as in other resource limited countries [38,39]. The high-cost, sophisticated procedural requirements and maintenance need to limit HIV RNA assays to few central laboratories. Therefore, robust, simple, affordable, and easily maintained in-house methods are required as an alternative to the commercially available viral RNA quantitation. This is the first study evaluating the use of an in-house HIV real-time RT-PCR assay as a suitable alternative to the commercial HIV RNA assays for monitoring HIV-infected patients in Ghana.

In developing the assay, we took into account that for resourcelimited countries, special attention should be paid to the high genotypic diversity of HIV in these regions. Subtyping was therefore performed on a subset of the samples used in this study and revealed the presence of at least five subtypes and a number of unique recombination. CRF02_AG is the major driver of HIV infection in Ghana and others in minor proportion of circulation such as CRF06_cpx, sub-subtype A3, CRF09_cpx and subtypes A, G and D had been identified. Studies have shown that RT activity is independent of the HIV-subtype [4045]. This is in agreement with other studies that evaluated an in-house real-time RT-PCR assay that targeted the same Long Terminal Repeat (LTR) region probing for viral RNA. The LTR region is one of the more conserved regions of the HIV-1 genome and therefore perfectly suitable for the development of assays with broad subtype specificity [46-49].

Real time PCR was carried out in a closed system without PCR post treatment (no gel analysis is needed), and so the risk of contamination was substantially reduced. The qRT-PCR assay out performs previous clinical diagnostics not only because of its speed, lower contamination risk, and ability for quantification but also because of its higher sensitivity and specificity for the RNA determination of clinical specimens [50]. In this study, primers and TaqMan probes were designed, and PCR conditions were defined for efficient amplification and quantitation of HIV RNA. An $\mathrm{HIV}_{\mathrm{NL4}-3}$ amplicon standard of a 503bp highly conserved sequence from LTR gene was made by conventional PCR to estimate analytically the quantitative RT-PCR assay. The qRTPCR assay established in this study was shown to have a good linearity $\left(R^{2}=1.0\right)$, a high PCR amplification efficiency (1.91), a high sensitivity (180 copies $/ \mathrm{ml}$ ), and a good reproducibility (variation coefficient range from $1.25 \%$ to $3.58 \%$ ). In this study, we used a relatively stable HIV amplicon DNA as an external standard because handling of DNA is easier and safer than RNA. Compared with the gold standard RealTime HIV-1 assay (Abbott), the specificity and sensitivity of the assay for detection of the HIV RNA in clinical samples were $96.7 \%$ and $95.0 \%$, respectively, which were close to those of the quantitative RT-PCR for detection of other RNA virus in clinical specimens [50]. Hence, the 74.6\% viral suppression in HIV patients as detected by the application of the in-house assay system gives indication that management of HIV patients on ART in Ghana is efficient. However, varying levels of viral load detected in $25.4 \%$ of patients is worrisome and therefore calls for a pragmatic program of longitudinal study to follow-up on this group of patients for effective clinical management to prevent them from developing resistant mutations. On the basis of the overall results obtained in the study, we conclude that the assay could be useful in poorresource settings to measure HIV viral load in clinical samples for the management of patients on ART. This study confirmed that in general TaqMan qRT-PCR is one of the most appealing techniques in the field of basic research and molecular laboratory diagnosis for quantification of nucleic acids [51] adoptable as an in-house for resource limited setting especially in south Saharan African countries like Ghana.

\section{Conclusions}

We have developed in-house quantitative real-time RT-PCR assay system for HIV-1 viral load measurement which is rapid, simple, and cost-efficient therefore very suitable for resourse-limiting settings. The validity of this assay has been confirmed by its application to evaluate the efficacy of ART in Ghanaian patients. 
Citation: Barnor JS, Yamamoto N, Brandful JAM, Ampofo W, Bonney JHK, et al. (2014) Establishment of In-House Quantitative Real-Time RT-PCR Assay for HIV-1 Viral Load Measurement: Application to Evaluate Efficacy of ART in Ghanaian Patients in an Urban Setting . J AIDS Clin Res 5: 305. doi:10.4172/2155-6113.1000305

\section{Acknowledgements and Funding}

We thank the Japan Initiative for Global Research Network on Infectious Diseases (J-GRID) and the Tokyo Medical and Dental University (TMDU) for their outstanding technical assistance and funding for the project. We thank Dr. Kwame Anim Boamah (Director of the Koforidua Government Hospital) for permission to use the facility for the study. We also thank the staff for their kind cooperation in the present study subject recruitment, sampling and running of biochemistries for the study patients, thus especially Mr. George Danquah Damptey, Mr. Richard Ansong, Mrs. Gifty Tetebo and Mr. Samuel Morton for their immense technical contributions. Appreciation finally goes to all the technical staff of the Virology Department of NMIMR for their various technical inputs.

\section{References}

1. Valdiserri RO, Ogden LL, McCray E (2003) Accomplishments in HIV prevention science: implications for stemming the epidemic. Nat Med 9: 881-886.

2. Ivers LC, Kendrick D, Doucette K (2005) Efficacy of antiretroviral therapy programs in resource-poor settings: a meta-analysis of the published literature. Clin Infect Dis 41: 217-224.

3. World Health Organization (2006) Antiretroviral therapy for HIV Infection in adults and adolescents. Recommendations for a public health approach. HIV/ AIDS Programme, WHO

4. Mellors JW, Rinaldo CR Jr, Gupta P, White RM, Todd JA, et al. (1996) Prognosis in HIV-1 infection predicted by the quantity of virus in plasma. Science 272 : $1167-1170$

5. Saag MS, Holodniy M, Kuritzkes DR, O'Brien WA, Coombs R, et al. (1996) HIV viral load markers in clinical practice. Nat Med 2: 625-629.

6. World Health Organization (2006) Towards universal access by 2010 . How WHO is working with countries to scale-up HIV prevention, treatment, care and support. World Health Organization, Geneva.

7. WHO (2006) Progress on global access to HIV antiretroviral therapy: a report on " 3 by 5 " and beyond, World Health Organization, Geneva.

8. Petti CA, Polage CR, Quinn TC, Ronald AR, Sande MA (2006) Laboratory medicine in Africa: a barrier to effective health care. Clin Infect Dis 42: 377-382.

9. Kaplan JE, Hanson DL, Jones JL, Dworkin MS; Adult and Adolescent Spectrum of HIV Disease Project Investigators (2001) Viral load as an independent risk factor for opportunistic infections in HIV-infected adults and adolescents. AIDS 15: $1831-1836$.

10. Hodinka RL (1998) The clinical utility of viral quantitation using molecular methods. Clin Diagn Virol 10: 25-47.

11. Berger A, Braner J, Doerr HW, Weber B (1998) Quantification of viral load clinical relevance for human immunodeficiency virus, hepatitis B virus and hepatitis $C$ virus infection. Intervirology 41: 24-34.

12. Back DJ, Khoo SH, Gibbons SE, Barry MG, Merry C (2000) Therapeutic drug monitoring of antiretrovirals in human immunodeficiency virus infection. Ther Drug Monit 22: 122-126.

13. Dax EM, Arnott A (2004) Advances in laboratory testing for HIV. Pathology 36 : $551-560$

14. Clarke JR (2002) Molecular diagnosis of HIV. Expert Rev Mol Diagn 2: 233-239.

15. Romano JW, van Gemen B, Kievits T (1996) NASBA: a novel, isothermal detection technology for qualitative and quantitative HIV-1 RNA measurements. Clin Lab Med 16: 89-103.

16. Nolte FS (1998) Branched DNA signal amplification for direct quantitation of nucleic acid sequences in clinical specimens. Adv Clin Chem 33: 201-235.

17. Katzenstein D, Laga M, Moatti JP (2003) The evaluation of the HIVIAIDS drug access initiatives in Côte d'Ivoire, Senegal and Uganda: how access to antiretroviral treatment can become feasible in Africa. AIDS 17 Suppl 3: S1-4.

18. Calmy A, Pascual F, Ford N (2004) HIV drug resistance. N Engl J Med 350 2720-2721.

19. Bourlet T, Signori-Schmuck A, Roche L, Icard V, Saoudin H, et al. (2011) HIV-1 load comparison using four commercial real-time assays. J Clin Microbiol 49: 292-297.

20. Drosten C, Seifried E, Roth WK (2001) TaqMan 5'-nuclease human immunodeficiency virus type 1 PCR assay with phage-packaged competitive internal control for high-throughput blood donor screening. J Clin Microbiol 39: 4302-4308.
21. Damond F, Roquebert B, Bénard A, Collin G, Miceli M, et al. (2007) Human immunodeficiency virus type 1 (HIV-1) plasma load discrepancies between the Roche COBAS AMPLICOR HIV-1 MONITOR Version 1.5 and the Roche COBAS AmpliPrep/COBAS TaqMan HIV-1 assays. J Clin Microbiol 45: 34363438.

22. Gueudin M, Plantier JC, Lemée V, Schmitt MP, Chartier L, et al. (2007) Evaluation of the Roche Cobas TaqMan and Abbott RealTime extractionquantification systems for HIV-1 subtypes. J Acquir Immune Defic Syndr 44: 500-505.

23. Rouet F, Ménan H, Viljoen J, Ngo-Giang-Huong N, Mandaliya K, et al. (2008) In-house HIV-1 RNA real-time RT-PCR assays: principle, available tests and usefulness in developing countries. Expert Rev Mol Diagn 8: 635-650.

24. Rouet F, Rouzioux C (2007) HIV-1 viral load testing cost in developing countries: what's new? Expert Rev Mol Diagn 7: 703-707.

25. Niesters HG (2002) Clinical virology in real time. J Clin Virol 25 Suppl 3: S3-12.

26. WHO (2006) WHO case definitions of HIV for surveillance and revised clinica staging and immunological classification of HIV related disease in adults and children. World Health Organization, Geneva.

27. Malmsten A, Shao XW, Aperia K, Corrigan GE, Sandström E, et al. (2003) HIV1 viral load determination based on reverse transcriptase activity recovered from human plasma. J Med Virol 71: 347-359.

28. Adachi A, Gendelman HE, Koenig S, Folks T, Willey R, et al. (1986) Production of acquired immunodeficiency syndrome-associated retrovirus in human and nonhuman cells transfected with an infectious molecular clone. J Virol 59: 284 291

29. Takahoko M, Tobiume M, Ishikawa K, Ampofo W, Yamamoto N, et al. (2001) Infectious DNA clone of HIV type 1 A/G recombinant (CRF02_AG) replicable in peripheral blood mononuclear cells. AIDS Res Hum Retroviruses 17: 10831087.

30. Malmsten A, Shao XW, Sjödahl S, Fredriksson EL, Pettersson I, et al. (2005) Improved HIV-1 viral load determination based on reverse transcriptase activity recovered from human plasma. J Med Virol 76: 291-296.

31. Mygind T, Birkelund S, Birkebaek NH, Østergaard L, Jensen JS, et al. (2002) Determination of PCR efficiency in chelex-100 purified clinical samples and comparison of real-time quantitative PCR and conventional PCR for detection of Chlamydia pneumoniae. BMC Microbiol 2: 17.

32. Burns MJ, Nixon GJ, Foy CA, Harris N (2005) Standardisation of data from real-time quantitative PCR methods - evaluation of outliers and comparison of calibration curves. BMC Biotechnol 5: 31.

33. Chen Z, Swisshelm K, Sager R (1994) A cautionary note on reaction tubes for differential display and cDNA amplification in thermal cycling. Biotechniques 16: 1002-1004, 1006.

34. Majchrowicz M (2003) Beyond antiretroviral access: low-cost laboratory tests needed for the developing world. AIDS 17 Suppl 4: S13-15

35. AIDS Info (2006) Guidelines for the use of antiretroviral agents in HIV-1-infected adults and adolescents. Centers for Disease Control and Prevention.

36. Stephenson J (2002) Cheaper HIV drugs for poor nations bring a new challenge: monitoring treatment. JAMA 288: 151-153.

37. Fiscus SA, Cheng B, Crowe SM, Demeter L, Jennings C, et al. (2006) HIV-1 viral load assays for resource-limited settings. PLoS Med 3: e417.

38. Yin WY, Zhang FJ, Juniper N, Wu ZY (2009) Improving China's antiretroviral treatment program: assessing current and future performance using the principals of ethics. Chin Med J (Engl) 122: 1346-1351.

39. Zhang F, Dou Z, Ma Y, Zhao Y, Liu Z, et al. (2009) Five-year outcomes of the China National Free Antiretroviral Treatment Program. Ann Intern Med 151 241-251, W-52.

40. Braun J, Plantier JC, Hellot MF, Tuaillon E, Gueudin M, et al. (2003) A new quantitative HIV load assay based on plasma virion reverse transcriptase activity for the different types, groups and subtypes. AIDS 17: 331-336.

41. Jennings C, Fiscus SA, Crowe SM, Danilovic AD, Morack RJ, et al. (2005) Comparison of two human immunodeficiency virus (HIV) RNA surrogate assays to the standard HIV RNA assay. J Clin Microbiol 43: 5950-5956.

42. Malmsten A, Shao XW, Aperia K, Corrigan GE, Sandström E, et al. (2003) HIV1 viral load determination based on reverse transcriptase activity recovered from human plasma. J Med Virol 71: 347-359. 
Citation: Barnor JS, Yamamoto N, Brandful JAM, Ampofo W, Bonney JHK, et al. (2014) Establishment of In-House Quantitative Real-Time RT-PCR Assay for HIV-1 Viral Load Measurement: Application to Evaluate Efficacy of ART in Ghanaian Patients in an Urban Setting . J AIDS Clin Res 5: 305. doi:10.4172/2155-6113.1000305

Page 7 of 7

43. Seyoum E, Wolday D, Girma M, Malmsten A, Meselle T, et al. (2006) Reverse transcriptase activity for quantitation of HIV-1 subtype $\mathrm{C}$ in plasma: relation to RNA copy number and CD4 T-cell count. J Med Virol 78: 161-168.

44. Sivapalasingam S, Essajee S, Nyambi PN, Itri V, Hanna B, et al. (2005) Human immunodeficiency virus (HIV) reverse transcriptase activity correlates with HIV RNA load: implications for resource-limited settings. J Clin Microbiol 43: 37933796.

45. Stevens G, Rekhviashvili N, Scott LE, Gonin R, Stevens W (2005) Evaluation of two commercially available, inexpensive alternative assays used for assessing viral load in a cohort of human immunodeficiency virus type1 subtype $\mathrm{C}$-infected patients from South Africa. J Clin Microbiol 43: 857-861.

46. Drosten C, Panning M, Drexler JF, Hänsel F, Pedroso C, et al. (2006) Ultrasensitive monitoring of HIV-1 viral load by a low-cost real-time reverse transcription-PCR assay with internal control for the $5^{\prime}$ long terminal repeat domain. Clin Chem 52: 1258-1266.

47. Rouet F, Chaix ML, Nerrienet E, Ngo-Giang-Huong N, Plantier JC, et al.
(2007) Impact of HIV-1 genetic diversity on plasma HIV-1 RNA quantification: usefulness of the Agence Nationale de Recherches sur le SIDA SecondGeneration Long Terminal Repeat-Based Real-Time Reverse Transcriptase Polymerase Chain Reaction Test. J Acquir Immune Defic Syndr 45: 380-388.

48. Rouet F, Ekouevi DK, Chaix ML, Burgard M, Inwoley A, et al. (2005) Transfer and evaluation of an automated, low-cost real-time reverse transcription-PCR test for diagnosis and monitoring of human immunodeficiency virus type 1 infection in a West African resource-limited setting. J Clin Microbiol 43: 27092717.

49. Rouet F, Ménan H, Viljoen J, Ngo-Giang-Huong N, Mandaliya K, et al. (2008) In-house HIV-1 RNA real-time RT-PCR assays: principle, available tests and usefulness in developing countries. Expert Rev Mol Diagn 8: 635-650.

50. Hummel KB, Lowe L, Bellini WJ, Rota PA (2006) Development of quantitative gene-specific real-time RT-PCR assays for the detection of measles virus in clinical specimens. J Virol Methods 132: 166-173.

51. Klein D (2002) Quantification using real-time PCR technology: applications and limitations. Trends Mol Med 8: 257-260. 